\title{
Ultrasound processing of liquid system(s) and its antimicrobial mechanism of action
}

Article

Accepted Version

Spiteri, D., Chot-Plassot, C., Sclear, J., Karatzas, K. A., Scerri, C. and Valdramidis, V. (2017) Ultrasound processing of liquid system(s) and its antimicrobial mechanism of action. Letters in Applied Microbiology, 65 (4). pp. 313-318. ISSN 0266-8254 doi: https://doi.org/10.1111/lam.12776 Available at https://centaur.reading.ac.uk/71448/

It is advisable to refer to the publisher's version if you intend to cite from the work. See Guidance on citing.

To link to this article DOI: http://dx.doi.org/10.1111/lam.12776

Publisher: Wiley

All outputs in CentAUR are protected by Intellectual Property Rights law, including copyright law. Copyright and IPR is retained by the creators or other copyright holders. Terms and conditions for use of this material are defined in the End User Agreement.

\section{www.reading.ac.uk/centaur}

\section{CentAUR}

Central Archive at the University of Reading 
Reading's research outputs online 
1 Ultrasound processing of liquid system(s)

2 and its antimicrobial mechanism of action

3

4

5

6

7

8

9

10

11

13

14

15

16

17

18

19

20

21

22

23

24

25

David Spiteri $^{1,2}$, Claire Chot-Plassot ${ }^{1}$, Julie Sclear ${ }^{1}$, Kimon Andreas Karatzas ${ }^{3}$, Chris Scerri ${ }^{2,4}$ and Vasilis Valdramidis ${ }^{1,2}$

${ }^{1}$ Department of Food Studies and Environmental Health, University of Malta,

${ }^{2}$ Centre for Molecular Medicine and Biobanking, University of Malta

${ }^{3}$ Department of Food and Nutritional Science, University of Reading,

${ }^{4}$ Department of Physiology and Biochemistry, University of Malta

e-mail: vasilis.valdramidis@um.edu.mt

Running head: Ultrasound processing of liquids

\section{SIGNIFICANCE AND IMPACT OF THE STUDY}

This study looks at the mechanism of action of ultrasound technology for the disinfection of wastewater. Different mutants with deleted genes were used to study the respective sensitivity or resistance to this treatment. This is essential to characterise changes at the molecular level, which might be occurring during treatment, resulting in bacterial adaptation.

\section{EXTENDED ABSTRACT}

Ultrasound creates cavitation phenomena, resulting in the formation of several free radicals, namely $\mathrm{OH} \bullet$ and $\mathrm{H} \bullet$, due to the breakdown of the $\mathrm{H}_{2} \mathrm{O}$ molecule. These 
radicals affect the cellular integrity of the bacteria, causing the inactivation of several processes, and thus it is important to unravel the mechanism of action of this technology. This research looks into the application and mechanism of action of ultrasound technology as a means of disinfection by acoustic cavitation. Sterile water and synthetic waste water were inoculated with different mutants of $E$. coli $\mathrm{K} 12$ strains containing deletions in genes affecting specific functional properties of $E$. coli. These were: dnak soxR, soxS, oxyR, rpoS, gadA/gadB, gadC and yneL. E. coli K-12 $\Delta$ oxyR, appeared to be more resistant to the treatment together with gadW, gadX, gabT and gabD, whereas the mutant $\mathrm{K}-12 \Delta d n a K$ was more sensitive with approximately $2.5 \mathrm{log}$ $(\mathrm{CFU} / \mathrm{mL})$ reduction in comparison to their isogenic wild type E. coli $\mathrm{K}-12$. This indicates that the dnaK gene participates in general stress response and more specifically to hyperosmotic stress. The other E. coli deleted genes tested (soxS, rpoS, gadB, gadC, yneL) did not appear to be involved in protection of microbial cells against ultrasound.

Keywords: ultrasound, E. coli $\mathrm{K} 12$, ultrasound, mutant cells, mechanism of action, GABA, GAD system

\section{INTRODUCTION}

Europe has extensive water resources compared to other regions of the world, and water has long been considered an inexhaustible public commodity. However, this position has been challenged in the last decades by growing water stress, both in terms of water scarcity and water quality deterioration. Indeed, in recent years, approximately half of the European countries, representing almost $70 \%$ of the population, have been facing water stress issues (Wintgens et al. 2006). Treatment of wastewater, has been a decade long practice for many European countries. Before 2011, most of the raw 
sewage was discharged back into the sea, without being treated, which is against the current EU Urban Waste Water directive (91/271/EEC). A study published in 2006 by Bixio et al. (2006), summarising the European water reuse practices and set out the map of the water reclamation technologies and reuse applications concluding that almost $70 \%$ of the population were facing water stress.

The quality requirements for wastewater reuse are predominantly oriented towards the planned usage and they are regulated in norms and legal provisions specific to each country. Besides the residual concentration of inorganic nutrients, total suspended solids and dissolved organic matter, the microbiological contamination of wastewater is an important criterion for its safe reuse (Haaken et al. 2014). Indeed, several pathogenic microorganisms and parasites are commonly found in domestic wastewater and in effluents from wastewater treatment plants. Three categories of pathogens are encountered in the environment: bacterial pathogens, including indigenous aquatic bacteria, viral pathogens and protozoan parasites. Wastewater bacteria have been characterized and belong to the following groups: Gram-negative facultatively anaerobic bacteria (e.g. Aeromonas, Vibrio, Enterobacter, Escherichia, Klebsiella, Shigella), Gram-negative aerobic bacteria (e.g. Pseudomonas, Alcaligenes, Flavobacterium, Acinetobacter), Gram-positive spore forming bacteria (e.g. Bacillus spp) and nonspore-forming Gram-positive bacteria (e.g. Arthrobacter, Corynebacterium, Rhodococcus) (Bitton, 2005; Machnicka, 2014). Escherichia coli is one of the main indicators for assessing the quality of wastewater.

As of recently, the application of ultrasonic technology has received wide attention in water and wastewater treatment and environmental remediation areas, including the application for disinfection purposes (Chen, 2012; Han et al., 2013; Cesaro and Belgiorno, 2016). Ultrasound generates elastic vibrations and waves whose frequency is over $15-20 \mathrm{kHz}$. Whilst ultrasound can stimulate the activity and growth of 
81 microorganisms at low intensities and small influence durations, at greater intensities

82 it kills and inactivates microorganisms. Long term water treatment by ultrasound of 20

$83-100 \mathrm{kHz}$ with a sound intensity of between 10 and $1,000 \mathrm{~W} / \mathrm{cm}^{2}$ can achieve 84 disinfection (Vasilyak 2011).

The disinfection capacity of sonication in water is due to the phenomenon of acoustic cavitation, which is the formation and collapse of micro-bubbles occurring in milliseconds, producing extreme temperature and pressure gradients (Drakopoulou et al. 2009; Sango et al. 2014). Indeed, the collapse of these micro-bubbles leads to extremely high local temperatures and pressures. These conditions have shown to result in the generation of highly reactive radicals. Ultrasound is therefore able to inactivate bacteria and de-agglomerate bacterial clusters through a number of physical, mechanical, and chemical effects caused by acoustic cavitation (Antoniadis et al. 2007; Broekman et al. 2010; Vasilyak, 2011). Nevertheless, to the knowledge of the authors, there are no studies focusing on identifying the major effects of sonication stress, and particularly the characterisation of mechanisms of microbiological responses of wastewater microorganisms under ultrasound treatment. Several similar studies on the mode of action has been carried out on other novel disinfection technologies such as plasma, ozone and nanomaterials (Laroussi 1996; Mahapatra et

101 ultrasound would be essential for fully understanding the microbial responses of $E$. coli and thus its efficient use in industrial applications.

104 The aim of this study is to assess the antimicrobial mechanisms of action of ultrasound on $E$. coli by performing a comparative study between wild type bacteria and selected

106 mutants that have important general stress tolerance genes deleted. The outcome 107 aims to address the role of several knock-out genes in the protection or sensitivity 108 against ultrasound generated radicals. 
111 In this experiment, the medium effect on free radical formation during ultrasound

112 treatments was studied. Results indicate that the only significant difference between

113 the different media was observed in the dnaK mutant. It should be emphasized that in

114 this case, the dnaK mutant was mostly affected by temperature. Table 2 illustrates the

115 behaviour of all the mutant strains in comparison to their isogenic wild type E. coli K-

116 12. It appears clearly that the mutant $\Delta o x y R$ was more resistant to the treatment

117 (reduction of $0.60 \mathrm{log}$ ) whereas $\Delta d n a K$ was nearly as sensitive as the wild type after 3

118 minutes of continuous treatment, even though temperature was controlled. For all

119 other mutants, the reduction was similar to that of E. coli K-12 wild type. On average,

120 most of the mutants, similarly to the wild type, showed a 1 log reduction.

121 The temperature profiles obtained show that from the three different treatments, all 122 showed a significant difference on the heating rate between the three different set-ups.

123 The controlled temperature treatment resulted in $0.1029^{\circ} \mathrm{C} / \mathrm{s}$ and a final temperature

$12439.5^{\circ} \mathrm{C}$, non-temperature controlled treatment with a heating rate of $0.2008^{\circ} \mathrm{C} / \mathrm{s}$ and a

125 final temperature of $58.3^{\circ} \mathrm{C}$ and with just cold water $0.1209^{\circ} \mathrm{C} / \mathrm{s}$ with a maximum

126 temperature of $44.5^{\circ} \mathrm{C}$. Thus, it is evident that in some of the mutants, the log reduction

127 observed, is related to ultrasound activity rather than the temperature as shown in table

128 2. In fact, according to Patil et al. (2011), the soxR, soxS, oxyR, rpoS and dnaK genes

129 have been reported to play an important role in the protection against reactive oxygen

130 radicals. As explained previously, one of the phenomena induced by cavitation is the

131 formation of radicals $\mathrm{H}^{\bullet}$ and $\mathrm{OH}^{\bullet}$ and of $\mathrm{H}_{2} \mathrm{O}_{2}$ (Joyce et al. 2003), which are known to

132 provoke oxidative stress in bacteria. The experimental results show that not all mutants

133 were affected in the same way by the ultrasonic treatment.

135 Two of the most affected mutants were found to be $\Delta o x y R$ and $\Delta d n a K$ (temperature)

136 mutants. The OxyR subunit of RNA polymerase is the master regulator of hydrogen 
peroxide genes in $E$. coli as it positively regulates the production of surface proteins

138 that control the colony morphology and auto-aggregation ability. The DnaK protein is,

139 among other, essential for growth at high temperatures and plays a role in the

140 regulation of the heat shock response. The heat shock response is an inducible cellular

141 response to a variety of stresses such as heat, exposure to ethanol, oxidants, and

142 DNA-damaging agents, production of abnormal proteins, viral infections, and

143 starvation for nutrients (Bukau and Walker 1989). The deletion of the dnaK gene can

144 explain the sensitivity of the corresponding mutant was particularly sensitive to heat in

145 the ultrasound experiments where the temperature during the treatment was not

146 controlled. It can also be an explanation to the fact that this mutant which was more

147 sensitive to the ultrasonic treatment than the $\mathrm{K}-12$ wild type of $E$. coli, as ultrasounds

148 lead to an oxidative stress on bacteria. Deletion of dnaK resulted in a sensitive

149 phenotype, to ultrasound, although the bacterial populations were not completely

150 inactivated with the applied treatment. This dnaK gene would therefore play a role in

151 the protection against ultrasound treatment of the bacteria.

153 Under the conditions tested, the mutant $\mathrm{K}-12 \Delta$ oxy $R$ appeared to be more resistant to

154 the treatment whereas the $\mathrm{K}-12 \Delta d n a K$ was more sensitive in comparison with the wild

155 type strain (Table 2). The dnaK would therefore play a role in the protection against

156 ultrasound treatment of the bacteria, and the corresponding mutant also shows a great

157 sensitivity to the heat generated during the ultrasonic treatment. An interesting

158 observation that needs to be noted is that involving $\Delta$ oxy $R$. The oxyR controls the

159 expression of a set of genes that constitute the oxy $R$ regulon. The OxyR protein is

160 produced constitutively and is oxidized by $\mathrm{H}_{2} \mathrm{O}_{2}$. The oxidized form of OxyR binds to

161 promoter regions of target genes and activates transcription by protein-protein contact

162 with RNA polymerase. The OxyR-activated genes have direct and indirect antioxidant

163 functions in the defence of the cell, such as removal of $\mathrm{H}_{2} \mathrm{O}_{2}$ by catalase and the

164 protection of DNA from oxidative attack by the Dps protein (Pomposiello and Demple 
165 2001). The current results show that this mutant was more resistant to ultrasound

166 indicating that the produced $\mathrm{H}_{2} \mathrm{O}_{2}$ during ultrasound treatments is not stable.

168 Furthermore, we also assessed mutants in genes associated with the GAD system 169 (Table 2) and found a possible role in ultrasound treatment. The GAD system is known 170 to play an important role in acid tolerance of bacteria (Smith et al. 1992, C. Feehily and 171 Karatzas 2013; Paudyal and Karatzas 2016) but it has been shown to play a role in 172 oxidative stress only in Saccharomyces cerevisiae (Coleman et al. 2001) and 173 Francisella tularensis (Ramond et al. 2014) but not in other organisms. This is the first 174 report showing a possible role for the GAD system in oxidative stress in E. coli. Here 175 we show that absence of the decarboxylase gadB did not affect survival (Table 2). 176 However, absence of gadA and gadC resulted in sensitivity when treatment occurred 177 without cold water and in resistance in synthetic wastewater. This might suggest a 178 differential role of the GAD system in different temperatures/conditions, or the 179 upregulation of alternative mechanisms that protect against oxidative stress under 180 specific conditions (e.g. synthetic wastewater).

182 We also assessed the role of other genes associated with the regulation of the GAD 183 system and the GABA shunt. Deletion of the GAD system regulators gadW, gadX, (

184 Tramonti et al. 2006; Sayed et al. 2007) resulted in resistance to ultrasound in sterile 185 water strengthening the role of the GAD system in oxidative stress. Similarly deletion 186 of $g a b T$ and $g a b D$ that encode for the GABA shunt that catabolise intracellular GABA 187 pools produced by the intracellular GAD system (Feehily et al. 2013), resulted in 188 resistance in sterile water but not in wastewater. It has been suggested that as the 189 GAD system coupled with the GABA shunt feed into the TCA cycle affecting the levels 190 of succinate and oxoglutarate that have anti-oxidant properties and can confer 191 resistance to oxidant species (Ramond et al. 2014) that might be produced during 
192 ultrasound treatment. However, further work is required to identify the above

193 hypothesis and other possible links between the GAD system and oxidative stress.

195 In conclusion, this research looked into the application and mechanism of action of 196 ultrasound technology as a means of disinfection by acoustic cavitation. Sterile water 197 and synthetic waste water were inoculated with different mutants of $E$. coli K12 strains 198 containing deletions in genes affecting specific functional properties of $E$. coli. E. coli

$199 \mathrm{~K}-12 \Delta o x y R$, appeared to be more resistant to the treatment together with gadW, gadX, 200 gabT and gabD, whereas the mutant K-12 $\Delta$ dnaK was more sensitive with 201 approximately $2.5 \log (\mathrm{CFU} / \mathrm{mL})$ reduction in comparison to their isogenic wild type $E$. 202 coli K-12. This indicated that the dnaK gene participates in general stress response 203 and more specifically to hyperosmotic stress. The other $E$. coli deleted genes tested 204 (soxS, rpoS, gadB, gadC, yneL) did not appear to be involved in protection of microbial 205 cells against ultrasound. Furthermore, we also showed for the first time here a possible 206 role of the GAD system in ultrasound treatment and oxidative stress that requires 207 further investigation, as these have shown that they are essentially crucial in the 208 protection from oxidative stress.

210 In the context of the wastewater recycling and reuse, the aim is to find a treatment

211 ensuring to remove or significantly reduce all the pathogens to minimize contamination 212 of the receiving waters and to provide public health protection. Ultrasound treatments 213 can be a potential technology for this type of treatments. 


\section{Materials and Methods}

\section{Bacterial strains and preparation of inoculum}

224 In this study, the bacterial strains used were E. coli K-12 wild type, and its isogenic 225 mutants $\Delta$ dnaK, $\Delta$ soxS, $\Delta$ soxR, $\Delta$ oxyR, $\Delta r p o S, \Delta g a d A$ (Jkl 3485), $\Delta g a d B(J k l ~ 1488)$ $226 \Delta g a d C$ (Jkl 1487) and $\Delta y n e L$ (Jkl 5247), all obtained from the National Bio-Resource 227 Project, Japan (NIG, Japan). A description of the mutants and their proteins' functions 228 is given in Table 1.

229 The pure cultures of strains were stored in vials at $-80^{\circ} \mathrm{C}$. Before any experiment, pure 230 cultures with isolated colonies were prepared. Under aseptic conditions, a loop from 231 the frozen vial was streaked on Tryptone Soya Agar (TSA; Oxoid, United Kingdom) 232 plates for E. coli. Following overnight incubation at $37^{\circ} \mathrm{C}$, these pure culture plates 233 were stored at $5^{\circ} \mathrm{C}$, and kept for 3 to 4 weeks the most until further use.

234 Experiments were performed in two types of liquid systems: (i) sterile water (SW) and 235 (ii) synthetic wastewater (SyW). The working solution to be treated was prepared by 236 diluting $2 \mathrm{~mL}$ of the working culture in $298 \mathrm{~mL}$ in SW or SyW in a $500 \mathrm{~mL}$ sterile beaker. 237 The SyW was prepared as described by Antionadis et al. (2007) and Ayyildiz et al. 238 (2011), i.e., peptone 64.0g/L; Meat Extract 44.0g/L; Urea 12.0g/L; $\mathrm{K}_{2} \mathrm{HPO}_{4} 11.2 \mathrm{~g} / \mathrm{L}$; $239 \mathrm{NaCl} 2.8 \mathrm{~g} / \mathrm{L} ; \mathrm{CaCl}_{2} .2 \mathrm{H}_{2} \mathrm{O}$ 1.6g/L; $\mathrm{MgSO}_{4} .7 \mathrm{H}_{2} \mathrm{O}$ 0.8g/L).

\section{Ultrasound treatments}

242 The inoculated solution was transferred to a jacketed beaker, which was used to pass 243 cold water, to avoid temperature increase during ultrasound. The ultrasonic equipment 244 used was a UP200St (Hielscher, Germany) comprising an ultrasonic generator 245 UP200St-G (200 W, frequency $26 \mathrm{kHz}$ ), and a transducer UP200St-T that could be 
246 integrated in a sound protection box. A temperature probe was connected to the

247 transducer and measured the temperature of the solution throughout the ultrasonic 248 treatment and that temperature profile was recorded on an integrated SD/USB 249 ComboCard. A $14 \mathrm{~mm}$ diameter sonotrode was used, and placed $2 \mathrm{~cm}$ deep in the 250 solution to be treated and was carefully cleaned between experiments with $70 \%$ 251 ethanol.

253 The first series of treatments were carried out applying an ultrasound treatment to the 254 working solutions of bacteria during 3 minutes in continuous mode, for all E. coli strains 255 using three conditions: (i) controlled temperature I (US-TI): Beaker was surrounded by 256 a cold water bath to keep the temperature lower than $45^{\circ} \mathrm{C}$; (ii) non controlled 257 temperature (US): Beaker was not placed in cold water bath in order to study the effect 258 of ultrasound in combination with the generated heat; (iii) Controlled temperature II 259 (US-TII): SyW was placed in a jacketed beaker, which was used to control the 260 temperature preventing it from increasing above $37^{\circ} \mathrm{C}$.

\section{Statistical analysis}

262 An F-test with $99.9 \%$ confidence level was used to check significance, within different 263 treatments, whilst a Bonferroni test correction was carried out to assess the 264 significance between each mutant.

266 Acknowledgment

267 This work was supported by a Malta Government Scholarship Scheme grant awarded 268 to David Spiteri and by the University of Malta Research Fund (Grant 269 DES/192/2014/46) 
272 No conflict of interest declared.

273 


\section{References}

Antoniadis, A., Poulios, I., Nikolakaki, E. and Mantzavinos, D. (2007) Sonochemical disinfection of municipal wastewater. $J$ Hazard Mater 146, 492-5.

Ayyildiz, O., Sanik, S. and Ileri, B. (2011) Effect of ultrasonic pretreatment on chlorine dioxide disinfection efficiency. Ultrason Sonochem 18, 683-688.

Bukau, B. and Walker, G. C. (1989) Cellular Defects Caused by Deletion of the Escherichia coli dnaK Gene Indicate Roles for Heat Shock Protein in Normal Metabolism. J Bacteriol 171, 2337-2346.

Cesaro, A. and Belgiorno, V. (2016) Removal of Endocrine Disruptors from Urban Wastewater by Advanced Oxidation Processes (AOPs): A Review. Open Biotechnol J Bentham Open Open Biotechnol J 10, 151-172

Coleman, S. T., Fang, T. K., Rovinsky, S. A., Turano, F. J. and Moye-Rowley, W. S. (2001) Expression of a glutamate decarboxylase homologue is required for normal oxidative stress tolerance in Saccharomyces cerevisiae. J Biol Chem 276, 244-50.

Drakopoulou, S., Terzakis, S., Fountoulakis, M. S., Mantzavinos, D. and Manios, T. (2009) Ultrasound-induced inactivation of gram-negative and gram-positive bacteria in secondary treated municipal wastewater. Ultrason Sonochem 16, $629-34$.

Feehily, C. and Karatzas, K. A. G. (2013) Role of glutamate metabolism in bacterial responses towards acid and other stresses. J Appl Microbiol 114, 11-24.

Feehily, C., O'Byrne, C. P. and Karatzas, K. A. G. (2013) Functional y-Aminobutyrate shunt in listeria monocytogenes: Role in acid tolerance and succinate biosynthesis. Appl Environ Microbiol 79, 74-80.

Haaken, D., Dittmar, T., Schmalz, V. and Worch, E. (2014) Disinfection of biologically treated wastewater and prevention of biofouling by UV/electrolysis hybrid 

technology: Influence factors and limits for domestic wastewater reuse. Water Res 52, 20-28.

302

Han, C., Andersen, J., Pillai, S.C., Fagan, R., Falaras, P., Byrne, J.A., Dunlop, P.S.M., Choi, H., Jiang, W., O'Shea K. and Dionysiou, D.D. (2013) Chapter green nanotechnology: Development of nanomaterials for environmental and energy applications ACS Symp Ser.

Joyce, E., Mason, T. J., Phull, S. S. and Lorimer, J.P. (2003) The development and evaluation of electrolysis in conjunction with power ultrasound for the disinfection of bacterial suspensions. Ultrason Sonochem 10, 231-234.

Laroussi, M. (1996) Sterilization of contaminated matter with an atmospheric pressure plasma. IEEE Trans Plasma Sci 24, 1188-1191.

Machnicka, A. (2014) Escherichia coli in sewage sludge - Detection Method. Chem Didact Ecol Metrol 19, 79-85.

Mahapatra, A. K., Muthukumarappan, K. and Julson, J. L. (2005) Applications of Ozone, Bacteriocins and Irradiation in Food Processing: A Review Crit Rev Food Sci Nutr 45, 447-461.

Nath, A., Mukhim, K., Swer, T., Dutta, D., Verma, N., Deka, B. C. and Gangwar, B. (2014) A Review on the Application of Nanotechnology in Food Processing and Packaging. J Food Prod Dev Packag 1, 07-21.

Patil, S., Valdramidis, V. P., Karatzas, K. a G., Cullen, P. J. and Bourke, P. (2011) Assessing the microbial oxidative stress mechanism of ozone treatment through the responses of Escherichia coli mutants. J Appl Microbiol 111, 136-44. https://doi.org/10.1111/j.1365-2672.2011.05021.x

Paudyal, R. and Karatzas, K. (2016) Chapter 10 - Stress adaptation of Listeria monocytogenes in acidic ready-to-eat products A2 - Kotzekidou, Parthena, $p$. 167-182, Food Hygiene and Toxicology in Ready to Eat Foods. Academic 
327 Perni, S., Shama, G., Hobman, J. L., Lund, P. A., Kershaw, C. J., Hidalgo-Arroyo, G.

Pomposiello, P. J. and Demple, B. (2001) Redox-operated genetic switches: the A., Penn, C.W., Deng, X.T., Walsh, J. and Kong, M. G. (2007) Probing bactericidal mechanisms induced by cold atmospheric plasmas with Escherichia coli mutants. Appl Phys Lett 90, 10-13.

Ramond, E., Gesbert, G., Rigard, M., Dairou, J., Dupuis, M., Dubail, I., Meibom, K.,

Sango, D. M., Abela, D., McElhatton, A. and Valdramidis, V. P. (2014) Assisted Henry, T., Barel, M. and Charbit, A. (2014) Glutamate Utilization Couples Oxidative Stress Defense and the Tricarboxylic Acid Cycle in Francisella Phagosomal Escape PLoS Pathog 10, e1003893.

$$
\text { ultrasound applications for the production of safe foods. J App/ Microbiol 116, }
$$
1067-1083.

Sayed, A. K., Odom, C. and Foster, J. W. (2007) The Escherichia coli AraC-family regulators GadX and GadW activate gadE, the central activator of glutamatedependent acid resistance. Microbiology 153, 2584-2592.

Smith, D. K., Kassam, T., Singh, B. and Elliott, J. F. (1992) Escherichia coli has two

346 Tramonti, A., De Canio, M., Delany, I., Scarlato, V. and De Biase, D. (2006)

347 Mechanisms of transcription activation exerted by GadX and GadW at the gadA 348 and gadBC gene promoters of the glutamate-based acid resistance system in 349 Escherichia coli. J Bacteriol 188, 8118-8127.

350 Vasilyak, L. M. (2011) Ultrasound application in systems for the disinfection of water. $351 \quad$ Surf Eng Appl Electrochem 46, 489-493. 
352 Wintgens, T., Bixio, D., Thoeye, C., Jeffrey, P., Hochstrat, R. and Melin, T. (2006)

353 Reclamation and reuse of municipal wastewater in Europe - current status and

354 future perspectives analysed by the AQUAREC research project.

355 http://www.iwrm-net.eu/sites/default/files/Aquarec_Policy\%20Brief_final_A4.pdf

$356 \quad$ (accessed 14 July 2017)

357

358

359

360

361

362

363

364

365

366

367

368

369

370

371

372

373

374

375

376

377

Table 1: Information on the E. coli (strain K12) genes deleted for the mutants studied

(adapted from (Patil et al. 2011); UniProt, 2014)

\section{Gene Protein encoded Protein functions}

DnaK participates actively in the response to hyperosmotic

shock.

Activates the transcription of the soxS gene which

Redox-sensitive itself controls the superoxide response regulons;

soxR transcriptional contains a $2 \mathrm{Fe}-2 \mathrm{~S}$ iron-sulfur cluster that may act as a

activator SoxR redox sensor system that recognizes superoxide, the

variable redox state of the Fe-S cluster is employed in 


\begin{tabular}{|c|c|c|}
\hline & & $\begin{array}{l}\text { vivo to modulate the transcriptional activity of SoxR in } \\
\text { response to specific types of oxidative stress. }\end{array}$ \\
\hline soxS & $\begin{array}{l}\text { Regulatory protein } \\
\text { SoxS }\end{array}$ & $\begin{array}{l}\text { Transcriptional activator of the superoxide response } \\
\text { regulon of E.coli that includes at least } 10 \text { genes such } \\
\text { as } \operatorname{sodA} \text {, nfo, zwf and micF; facilitates the subsequent } \\
\text { binding of RNA polymerase to the micF and the nfo } \\
\text { promoters. }\end{array}$ \\
\hline oxyR & $\begin{array}{l}\text { Hydrogen } \\
\text { peroxide-inducible } \\
\text { genes activator }\end{array}$ & $\begin{array}{l}\text { Hydrogen peroxide sensor; activates the expression } \\
\text { of a regulon of hydrogen peroxide-inducible genes; } \\
\text { positive regulatory effect on the production of surface } \\
\text { proteins that control the colony morphology and auto- } \\
\text { aggregation ability }\end{array}$ \\
\hline rpos & $\begin{array}{l}\text { RNA polymerase } \\
\text { sigma factor RpoS }\end{array}$ & $\begin{array}{l}\text { Master transcriptional regulator of the stationary } \\
\text { phase and the general stress response; controls } \\
\text { positively or negatively the expression of several } \\
\text { hundred genes which are mainly involved in } \\
\text { metabolism, transport, regulation and stress } \\
\text { management }\end{array}$ \\
\hline $\begin{array}{l}\operatorname{gad} A \\
\operatorname{gad} B\end{array}$ & $\begin{array}{l}\text { Glutamate } \\
\text { decarboxylase } \\
\text { alpha Glutamate } \\
\text { decarboxylase } \\
\text { beta }\end{array}$ & $\begin{array}{l}\text { Convert glutamate to gamma-aminobutyrate (GABA); } \\
\text { the gad system helps to maintain a near-neutral } \\
\text { intracellular pH when cells are exposed to extremely } \\
\text { acidic conditions. }\end{array}$ \\
\hline $\operatorname{gadC}$ & $\begin{array}{l}\text { Probable } \\
\text { glutamate/gamma- } \\
\text { aminobutyrate } \\
\text { antiporter }\end{array}$ & $\begin{array}{l}\text { Involved in glutamate-dependent acid resistance; } \\
\text { imports glutamate inside the cell while simultaneously } \\
\text { exporting to the periplasm the GABA produced by } \\
\text { GadA and GadB. }\end{array}$ \\
\hline
\end{tabular}




\section{Putative HTH-type \\ A predicted transcriptional regulator which controls \\ yneL transcriptional regulator YneL \\ the conversion of DNA to RNA and the gene activity.}

Table 2: Microbial log reduction of studied E. coli mutants under both controlled and freely increasing temperature. W: sterile distilled water, SyW: Sterile synthetic water. The values followed by the same letter, are not statistically significant within each row.

Log Reduction

386

Strain

Log Reduction

\begin{tabular}{|c|c|c|c|}
\hline & $\begin{array}{c}\text { US with cold } \\
\text { water (W) }\end{array}$ & $\begin{array}{l}\text { US without } \\
\text { cold water } \\
\text { (W) }\end{array}$ & $\begin{array}{c}\text { Temperature } \\
\text { controlled } \\
\text { US (SyW) }\end{array}$ \\
\hline $\begin{array}{c}\text { K-12 wild } \\
\text { type }\end{array}$ & $1.67 \pm 0.05^{\mathrm{a}}$ & $2.50 \pm 0.32^{\mathrm{a}}$ & $0.81 \pm 0.29^{a}$ \\
\hline$\Delta \operatorname{gadA}$ & $1.53 \pm 0.17^{\mathrm{a}}$ & $3.00 \pm 0.14^{b}$ & $0.83 \pm 0.18^{\mathrm{a}}$ \\
\hline$\Delta \operatorname{gadB}$ & $1.64 \pm 0.06^{a}$ & $2.49 \pm 0.40^{\mathrm{abc}}$ & $1.29 \pm 0.29^{\mathrm{ab}}$ \\
\hline$\Delta$ gadC & $1.77 \pm 0.06^{\mathrm{a}}$ & $3.33 \pm 0.57^{\mathrm{abcd}}$ & $0.87 \pm 0.20^{\mathrm{a}}$ \\
\hline$\Delta$ gadW & $0.51 \pm 0.08^{b}$ & $0.68 \pm 0.07^{\mathrm{e}}$ & $1.27 \pm 0.03^{b}$ \\
\hline$\Delta$ gadX & $0.29 \pm 0.08^{b}$ & $0.68 \pm 0.09^{\mathrm{e}}$ & $0.85 \pm 0.17^{a}$ \\
\hline$\Delta$ gabT & $0.69 \pm 0.07^{c}$ & $0.52 \pm 0.04^{\mathrm{ef}}$ & $0.75 \pm 0.00^{\mathrm{a}}$ \\
\hline$\Delta \mathrm{gabD}$ & $0.79 \pm 0.07^{c}$ & $0.52 \pm 0.02^{\text {ef }}$ & $1.33 \pm 0.32^{\mathrm{ab}}$ \\
\hline$\Delta r p o s$ & $1.53 \pm 0.12^{\mathrm{a}}$ & $2.18 \pm 0.40^{\mathrm{a}}$ & $1.42 \pm 0.34^{\mathrm{ab}}$ \\
\hline$\Delta d n a K$ & $2.11 \pm 0.20^{d}$ & $5.42 \pm 0.18^{h}$ & $0.98 \pm 0.10^{\mathrm{a}}$ \\
\hline$\Delta$ soxs & $1.80 \pm 0.13^{\text {ad }}$ & $2.24 \pm 0.22^{\mathrm{ac}}$ & $1.02 \pm 0.38^{\mathrm{ab}}$ \\
\hline$\Delta \mathrm{soxR}$ & $1.85 \pm 0.18^{\text {ad }}$ & $3.52 \pm 0.27^{d}$ & $1.56 \pm 0.53^{\mathrm{ab}}$ \\
\hline$\Delta O x y R$ & $0.60 \pm 0.38^{b c}$ & $0.83 \pm 0.05^{\mathrm{e}}$ & $0.42 \pm 0.08^{c}$ \\
\hline$\Delta y n e L$ & $1.78 \pm 0.12^{\text {ad }}$ & $2.97 \pm 0.15^{\mathrm{abcd}}$ & $1.22 \pm 0.35^{\mathrm{ab}}$ \\
\hline
\end{tabular}


403

404

405 